\title{
Die kerk van die Woord
}

\section{P B Boshoff}

Universiteit van Pretoria

Tydelike dosent: Departement Nuwe-Testamentiese Wetenskap (Afd A)

\begin{abstract}
The church proclaiming the Word

The theme of the church is treated from the perspective of the theology of the Word. 1 Corinthians 5:19 is analyzed in the process. Divine revelation is discussed in the light of its being in the nature of an once-and-forall event. This leads one to an understanding of the church in which the church best acquits itself of its task in public worship. The task of the church and the relationship between church and being a Christian are then considered.
\end{abstract}

\section{INLEIDING}

Die bedoeling met hierdie artikel is nie om 'n ewewigtige leerstuk oor die kerk voor te hou nie. Die werkwyse was om êrens 'n begin te maak en algaande te sien waarheen die pad lei. Dit het eers later moontlik geword om noukeuriger te sien waarheen die gedagtes gelei het. Dit is daarom miskien beter as ek nie nou al probeer sê waaroor dit sal gaan nie, sodat die leser ook gaandeweg deel van die struktuursamehang van die onderwerp kan word. Om as' $t$ ware van buite af 'n oorsig oor die saak te wil hê, kan volgens my aanvoeling maar net nie geluk nie, want die hele teologiese netwerk kom in beweging by 'n onderwerp soos hierdie.

Die vraag na die kerk kom in die loop van die teologiese nadenke altyd weer aan die orde. Verrassende, nuwe insigte en oorspronklike formulerings moet 'n mens dus nie verwag nie. Wat nuut is, is eerder die feit dat ook ons, in die omstandighede waarin ons verkeer, ' $n$ beurt kry om deel van die kerk te wees wat steeds gedwing word om homself beter te verstaan. Die verandering van die kerk ten opsigte van kategese, erediensordes en nou die kerkorde, wat die Nederduitsch Hervormde Kerk van Afrika spesifiek betref, is ' $n$ aanduiding van die noodsaak om te vernuwe. Dat die veranderings begelei word deur die vraag of die kerk aan sy aard getrou bly, gee te kenne dat

\footnotetext{
* Voordrag gelewer voor die jaarkongres van die Hervormde Teologiese Vereniging op 19 Junie 1995.
} 
dit uiteindelik om die inhoud van die kerklike boodskap, die erediens gaan. Daarom sal dit die beste wees om ons aandag te bepaal by die kerk en sy verkondiging en word die titel aangegee as 'die kerk van die Woord'.

\section{GEBEURE}

Dit het deel van die teologiese woordeskat geword om die term 'gebeure' (vgl Bultmann 1963:76) in verskillende samestellings te gebruik, byvoorbeeld heilsgebeure, openbaringsgebeure, verlossingsgebeure en selfs Christus-gebeure. Uitgaande van die veronderstelling dat dit nie ' $n$ onduidelike en willekeurige taalgebruik is nie, maar ' $n$ verantwoordelike, kan dit net lonend wees om na te gaan hoe hierdie verbindings inmekaar sit en funksioneer. 'Gebeure' in een of ander verbinding beklemtoon dat dit gaan om iets wat gebeur of geskied, in hierdie gevalle om die aksie van heil, openbaring en verlossing. Hoewel heilsgebeure 'n naamwoord is, word daaraan 'n verbale betekenis gegee, sodat dit werkwoordelik verstaan moet word. Die uitdrukkings met 'gebeure' is selfs intensiewer en meer dinamies as wat die aktiewe vorm 'God openbaar Hom' sou deurgee, want 'openbaringsgebeure' verwys na 'n groter werksaamheid en bedrywigheid as 'Hy openbaar Hom'. 'n Hele samespel van aktiwiteite word verwag en dit kan weergegee word met: God openbaar Hom deur die verkondiging, dit wil sê, deur mense sy Woord te laat verkondig en te laat glo.

Treffend word hierdie saak omskryf in die vroeg-kerklike formule, 2 Korintiërs 5:19 (kyk ook Schmithals 1994:76, 91-92):

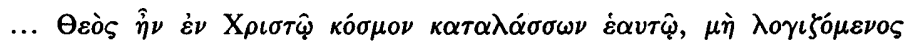

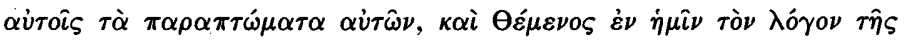
$\kappa \alpha \tau \alpha \lambda \lambda \alpha \gamma \eta \hat{\eta} \varsigma$. (God was in Christus die wêreld aan die versoen met Hom, sonder om die mense hulle oortredinge toe te reken en, nog meer,

Hy het onder ons die woord van die versoening ingestel).

${ }^{\top} \mathrm{H} \nu$ saam met die partisipium presens $\kappa \alpha \tau \alpha \lambda \alpha \dot{\alpha} \sigma \sigma \omega \nu$ is 'n omskryfde imperfektum en dien om die onvoltooide handeling te beskryf en word gevolg deur 'n klimaktiese $\kappa \alpha i$

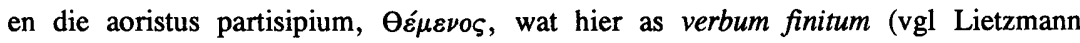
1969:127) diens doen en die handeling afsluit. Die gee van die woord van die versoening sluit die handeling af, wat begin met die uitdrukkingsvolle en besliste stelling, dat God in Christus die wêreld aan die versoen met Hom was. Die verloop van die handelinge dui daarop dat die instel van die woord van die versoening die voltooiing is van dit wat in Christus begin is. Die Christus-gebeure word deur die verkondiging in die regte perspektief gestel. Die omstandighede waaronder God die Woord ingestel het, was dat Hy besig was om die wêreld met Homself te versoen. Die manier waarop die 
Woord verkondig en gehoor sal word, sal dus wees dat die wêreld daardeur met God versoen sal word. Die versoeningsgebeure vind plaas wanneer mense deur die Woord so getref word dat hulle verander word van die ou onversoende mense na nuwe mense toe.

As heil, openbaring, verlossing en Christus met gebeure verbind kan word, moet daar iets gemeenskapliks tussen hierdie sake wees. Die een gebeure kan nie van die ander geïsoleer word nie. Die dinamiek maak dat waar die een ophou, gaan die volgende een weer verder, sonder dat daar 'n breuk kom. In werklikheid is die gemeenskaplikheid so groot dat dit eintlik net een sentrale gebeure is. Die verskillende verbindings benader elkeen dieselfde saak vanuit 'n bepaalde gesigspunt. Daar is selfs 'n uitdrukking wat bedoel is om so 'n samevatting te gee, naamlik eskatologiese gebeure. In hierdie geval tree gebeure nie in ' $n$ verbinding op nie, maar word absoluut gestel en nader omskryf met die bepaling 'eskatologiese'. Eskatologie is nie 'n woord uit die Bybelse woordeskat nie, maar 'n teologiese term, wat sedert die negentiende eeu na vore gekom het en aanvanklik die laaste dinge soos dood, oordeel en opstanding aangedui het. Gaandeweg het die begrip en saak van die eskatologie duideliker ingeprent geraak, sodat dit 'n samevatting van die geheel van die Christelike teologie geword het. Om hierdie aanspraak te regverdig kan die apokaliptiese vraag opgeneem word: Wanneer kom die heil dan? Wanneer breek die groot en blye dag aan? Hierop antwoord die vroeg-Christelike belydenis (Schmithals 1994:82): 'Toe die volheid van die tyd gekom het, het God sy Seun gestuur' (Gal 4:4).

Wat moet ons onder die volheid van die tyd verstaan? Wat is dit? Die woord 'volheid' laat 'n mens dink aan 'n inhoudsmaat, sê maar 'n kruik, waarin 'n bepaalde hoeveelheid vloeistof gegooi kan word. 'n Vol kruik is 'n akkurate aanduiding, want as dit oorvol is, sal dit wat te veel is, oorloop, en as daar te min vloeistof in is, is dit ook maklik om die tekort raak te sien. Tussen dit wat te veel sou wees en dit wat te min is, bring die presiese volle maat sy merk aan. Die kerklike verkondiging beroep hom daarop dat 'die tyd sy volle maat bereik het'. Dit beteken dat die merk bereik is waar daar geen gaping meer oorbly wat nog gevul moet word nie, dis nou vol, die tyd is voltooi. Die ou wêreld het sy tyd deurloop en sy grens bereik en 'n nuwe bedeling breek aan. Hierdie uitdrukking moet gehoor word teen die agtergrond van wat inense in daardie tyd verwag het. Hulle het verwag dat die koninkryk van God in die toekoms moet aanbreek deurdat die wêreld waarin die Satan heers, die wêreld van smart en onderdrukking sou verbygaan, en dat 'n nuwe wêreld van lig en lewe in sy plek sou kom. Die ou, godlose wêreld gaan tot niet en die nuwe hemel en die nuwe aarde kom in sy plek. Die ou toestand se maat moet heeltemal vol wees voordat die nuwe sy verskyning kan maak. Die vroegste kerk het hierdie voorstellings gewysig. Vir hulle 
is dit nie 'n kosmiese katastrofe wat 'n einde aan die ou bedeling maak nie. Nee, die oue loop dood en die nuwe begin met die stuur van die Seun van God. Daarmee word die bepaalde maat bereik, daaroor kan geen twyfel meer wees nie. Die kerk verkondig dat die historiese gebeurtenis, Jesus Christus, as die eskatologiese gebeure verstaan moet word. Wie die boodskap glo, word in die eskatologiese bestaan gestel waar 'n mens in die wêreld is, maar nie meer van die wêreld nie.

Deur sy Woord aan die kerk toe te vertrou om verkondigend die versoening te bewerk, gee God te kenne hoe Hy altyd en op alle plekke handel. Waar en wanneer die Woord verkondig word, kondig dit die eskatologiese gebeure van die koms van die nuwe bedeling aan. Maar die nuwe bedeling breek nie deur as die hoorder van die boodskap nie op God vertrou nie. Wanneer ons vra hoe 'n mens sover kom om God te vertrou, antwoord die kerklike belydenis: uit die hoor van die Woord (Rom 10:14). Daarom is die Woord so noodsaaklik, want dit is die enigste element waarin hierdie gebeure kan plaasvind. Deur die taal kan dit tot die menslike besef deurdring dat God aanspraak op die hoorder se vertroue maak. En die getroue Woord getuig altyd van een en dieselfde gebeure, altyd van die versoening van die wêreld met God. Die beskrywing van die erediens as ontmoetingsgebeure, wat verderaan bespreek word, sluit hierby aan en wil as begripsbepaling vir die openbaring as ' $n$ werklikheid op 'n persoonlike vlak dien. Die sin daarvan is meer werklik as 'n binnewêreldse objektiewe feit, wat ' $n$ abstraksie is en nie gebeur nie. God is transendent en nie binnewêrelds nie en daarom is die openbaring gebeurlik en nie feitelik nie.

\section{EENS EN VIR ALTYD}

Dit bring ons by die 'eens-en-vir-altydheid', die $\dot{\varepsilon} \phi \dot{\alpha} \pi \alpha \xi$ van die Nuwe-Testamentiese boodskap. Die eskatologiese gebeure begin, volgens die formule (2 Kor 5:19), daarmee dat God in Christus die wêreld met Hom aan die versoen was. Maar die bedoeling is nie dat dit ' $n$ gebeurtenis is wat destyds, eens, op 'n spesifieke datum, histories, gefikseer kan word nie. 'n Blote datering laat nog nie reg aan die saak geskied nie, want ons het gesien dat die verloop van die handelinge aantoon dat die verkondiging van die Woord ' $n$ voortsetting is van wat God in Christus aan die doen is (vgl Bultmann 1971:179). Die eenmalige wending van die ou na die nuwe bedeling het gekom en die verkondiging van die Woord van die versoening moet daartoe lei dat dit by nog meer en uiteindelik by almal deurbreek (Gunneweg 1967:91; Schmithals 1988:193). En dit gaan altyd om die een wending, dit is die beslissende een ding wat nodig is. Daarom bely die kerk dat Christus die enigste openbaring van God is: 'In hierdie laaste dae het Hy met ons gepraat deur die Seun' (Heb 1:2). 
Die merkwaardige van die Christelike openbaringsbegrip is dat die openbaring in Christus wat aan ' $n$ bepaalde, begrensde plek gebonde is, tog nie aanleiding gee om die Christus-gebeure as 'n afsonderlike openbaringsfeit te sien wat net 'n deel sou uitmaak van 'n groter geheel nie. Hoewel daar van een historiese openbaringsplek sprake is, 'God was in Christus die wêreld aan die versoen met Hom', word so daarvan getuienis afgelê dat dit die hoorders bring by die einde van die wêreldloop. Die wêreld waarin mense oor hulleself beskik en wat hulle gebruik om hulleself te verwesenlik, kom tot 'n einde en hulle vertrou hulle aan die genade van God toe. Die doel van die geskiedenis is bereik: 'Kyk nou is dit die regte tyd, nou is dit die dag van redding' (2 Kor 6:2). Die openbaring in Christus word deur die verkondiging tot die enigste en onoortrefbare openbaring van God gemaak. Ook die teenwoordigheid van die lewende God in die geskiedenis het nie ' $n$ ander inhoud en bedoeling as die openbaring in Christus nie. Of God werklik in Christus was, sal net dié mense weet wat deur die verkondiging tot die besef kom dat die verganklike wêreld nie die lewe aan die mens kan gee nie, want die is reeds veroordeel - dié mense wat terselfdertyd die lewe uit die hand van God verwag, ook midde in die dood.

Die woord van die versoening het egter die ervaring dat dit in mensemond terugsak uit die funksie om draer en bewerker van die versoening te wees tot ' $n$ blote verwysing na die versoening wat plaasgevind het. Die Woord is self dan nie meer kragtig nie, maar vertel eers agterna wat toe, destyds, gebeur het. Saam met die degradering van die Woord verander ook die gebeure waarvan dit vertel, van karakter. Daar word na die heilsgebeure verwys as ' $n$ afgehandelde saak wat in die verlede plaasgevind het. Die kruisgebeure word van die versoening in die hede geïsoleer en as 'n opsigselfstaande gebeurtenis in die verlede beskou, onafhanklik van die hoorder. Die boodskap van die versoening bring die mens nie meer by die einde van die ou wêreld waarin sonde, wet en dood heers nie, en die gevolg is dat daar 'n verlange na nog openbarings van God ontstaan. 'n Voorbeeld van hoe hierdie verlange uiting kan vind, is die hoop op 'n mistieke ervaring van God, soos Koos du Plessis dit verwoord:

Elke dag beloof 'n nuwe hawe;

telkens is daar vaste grond in sig

in oggendlig.

Elke aand word elke droom begrawe,

maar dan, een môre, keer die stemme t'rug;

sien ek, met die oë omhoog gerig,

'n visioen, ' $n$ vergesig:

'n sterrebrug!

'n land van lig!

(Du Plessis 1988:39) 
'n Tweede voorbeeld hoe die hunkering na nog openbarings van God neerslag kan vind, kom voor in die algemene eerbied wat daar vir sukses is. Volgens hierdie benadering word die proses van die geskiedenis deur suksesse aan die gang gehou en dit is God self wat agter elkeen staan. Die oorwinnaar is die gestuurde en die ander mense in die verhaal dien bloot as die agtergrond en as die weerstand teenoor wie hy seëvier. In sy roman Gelofteland gee Venter 'n beskrywing hoe die sukses as 'n goddelike openbaring, sienderoë, gekonstateer word:

Umhlela en Tambuza probeer keer, van die veterane probeer pal staan, maar die verdelging van die kanonvuur en die onkeerbare rydiere het die jonges - en baie oues - ingebreek. Hulle beur blindelings weg uit die verderf van dood, bloed en verminking.

Eers begin die buite-rand van die massa uitrafel en toe, onder die druk uit die binne-hart van die leer waar die ruiters na weerskante toe skiet en die kanonvuur 'n slagting aanrig, begin hulle hardloop.

Een deel hardloop na die sloot, een deel na die rivier.

'"n Daad van God!' fluister Rudolf, sy lippe droog en sy oë groot en verwonderd in sy swart gesig. '"n Daad van God!'

(Venter 1966:242)

So 'n kennis van God is egter nog nie ware kennis nie, maar onkunde. Waar triomfantelik oor God gepraat word, word Hy as 'n verlenging van die mens se eie wil gesien en nie as die Een wat die mens vind deur sy sonde te vergewe nie. Die mens het nog nie by die einde van die ou wêreld gekom nie, maar meen om dit voort te sit en glo dat God uit die geskiedenis geken kan word. Die boodskap wat hy bring, gaan oor die hand van God in die geskiedenis en nie oor die evangelie wat 'n einde aan die ou wêreld maak nie. Maar volgens die Christelike openbaringsbegrip kom God nie op so 'n wyse na die mens toe dat God in diens van die mens gestel word nie, maar eerder dat God mense in diens neem. Ook volgens die Ou Testament laat God Hom in sy woord vind, selfs as Jerusalem verwoes is en die volk in die vernederende ballingskap verkeer, sodat egte eskatologie ook in die Ou Testament deurgevoer word (Gunneweg 1977:185-186; 1993:123). Die eskatologiese heil wat in Christus gekom het, is nie iets nuuts in die $\sin$ van 'n moment in die historiese ontwikkeling nie. In Christus kom daar nie die volle openbaring wat alles voorafgaande tot iets voorlopigs bestempel nie; geen nuwe openbaring geskied in Christus nie, maar die een God wat altyd die lig van die mense was, word nuut betoon. Die heil wat deur die kerklike verkondiging gebring word, is verder die volle heil, nie net 'n gedeeltelike heil nie (vgl Loader 
1979:169). Die mens ontvang die heil egter nie as 'n besitting nie, maar moet dit altyd weer teen die ou bedeling in bekom, want die ou wêreld gaan nog voort. Die Christus-gebeure beteken die vernuwing van die heil wat altyd 'n moontlikheid vir die mense was. Die Woord wat die oorsprong is en in die begin was en die Woord wat vlees geword het, is identies. Die Woord wat nou verkondig word, stel mense voor die nuutheid van die Woord wat van die begin af gehoor kon word (Schmithals 1979:477).

Wat egter nie gevra word nie, is dat iemand uit die hoogte sou neersien op Rudolf Dreyer en sy opvatting. 'n Mens moet liewer hierin die vraag na die ware kennis van God, na God self aanvoel. Die mens wil weet of God bestaan, of God daar is. En die antwoord wat die kerk gee, is dat God in sy Woord is. 'n Mens moet na hierdie Woord luister. In die kerkgebou wat die Voortrekkers gebou het, sou Rudolf Dreyer die Woord kon hoor, as dit die Here behaag het.

\section{EREDIENS}

Die versoeningswerk van Christus kan nie van die versoeningswoord losgemaak word nie, beide hoort saam in die heilshandeling. As God die wêreld tussen die jare een tot dertig in 'n blote objektiewe gebeurtenis met Hom versoen het, sou die verkondiging nie nodig gewees het nie. Maar dit is nodig, want die versoeningsgebeure oorskrei die historiese, dit gaan steeds voort in ' $\mathrm{n}$ transendente dimensie en word aan mense oorgedra in die reddende andersheid daarvan. En die oordrag van die heilsgebeure in die reddende andersheid daarvan het die kerk tot gevolg, dit is die kerk in sy eskatologiese werklikheid. As eskatologiese werklikheid kan die heil nie op 'n ander manier in die wêreld as deur verkondiging grondvat nie (vgl Van Selms 1949:70). In die kerk, deur die kerklike verkondiging, kom die mens te staan voor die extra nos van die heil, dit wil sê, dat die heil op die mens wag wat nie self daaroor beskik nie, want dit word nie sigbaar in wat die mens doen nie, maar dit is tog teenwoordig, lokaliseerbaar, waar daar verkondig word: 'Ek lewe en julle sal lewe' (Joh 14:19). Selfs nog voordat die Woord gehoor word, is dit reeds daar. As sigbare Woord maak die sakramente duidelik dat dit al klaar gesê is. Die genade wag op die mens. En dit neem nie die feit weg dat die wese van die Woord daarin bestaan dat dit gehoor sal word nie. Van die begin af is die kerk met prediking en kultus dus betrek by die versoeningsgebeure. Daar kan aan die kerk nie eintlik anders gedink word as dat dit die versoening moet uitbring by die mense vir wie dit geld nie. Word dit nie gedoen nie, sou die versoening agterraak by die stryd wat die sonde teen die mens voer, en niks vermag nie.

Geen mens beskik daaroor dat mense inderdaad na hierdie Woord sou luister nie. Wanneer mense gehoor gee en die Woord vashou in hulle eie woorde en wete, is dit die werk van die Heilige Gees. As eskatologiese gebeure is die versoening die oorgang uit 
die ou bedeling na die nuwe en omdat hierdie eindtydlike oorgang plaasvind in die konkrete lewens van mense, kan die gcloof, waardeur mense deel daaraan kry, nooit afgehandel en voltooid wees nie. Die mens moet altyd weer die deelname aan die nuwe lewe ontvang.

Die kerk as omskrywing van die eskatologiese gebeure is daar waar die verkondiging in woord en sakrament gelowig aanvaar word en dit is dieselfde as dat God deur sy Woord mense tref. Daar kan nie kerk wees as daar nie mense is wat luister nie, en ook nie as die versoeningswoord nie klink nie. Hierdie twee dele kan nie as aanvanklik onafhanklik van mekaar beskou word met die voorneme dat hulle later bymekaar gebring moet word nie. Die erediens bring versoening tussen mens en God. Die menslike luister kom nie as 'n byvoeging by die openbaring van God nie, want die openbaring kan nie werklikheid word sonder die luister nie. In die luister is mense nie meer op hulleself aangewese, op wat hulle doen nie, maar op die Een wat met hulle praat, op wat God doen. Mense se aandeel aan die erediens is dat hulle ontvang. Waar die kultus beskou kan word as ' $n$ manier om invloed op die Godheid uit te oefen, moet die Christelike erediens as ontdaan van die kultiese ervaar word.

In die rekenskap wat van die erediens gegee word, word dit as 'n gesprek tussen God en gemeente voorgestel. Die mens antwoord op die Woord wat gehoor word. Die woord-antwoordkarakter van die erediens kan egter tot gevolg hê dat aan die antwoorder as 'n selfstandige subjek gedink word, wat teenoor God gestel is. Die outonome mens gee van sy kant af 'n gunstige antwoord in God se rigting. In plaas van so ' $n$ voorstelling moet dit duidelik gemaak word dat dit die omvormde mens is wat die antwoord uitkry. Die mens antwoord nie op die Woord nie, maar uit die Woord, want hy ontvang sy nuwe selfverstaan, sy antwoord uit die Woord. Die Woord kan nie homself wees as dit nie ' $n$ antwoord ontlok het nie. Die dikwels gebruikte beeldspraak van 'n ontmoeting tussen God en mens, in die lig van die eskatologiese gebeure, kan ook met vrug gebruik word. Hoewel 'n erediens in besonderhede voorberei word, dui ontmoeting in hierdie geval 'n samekoms aan wat nie met opset beplan en uitgevoer word nie. Die erediens is ontmoetingsgebeure tussen God en mens. Voorlopig kan ons sê dat die werklikheid van God en die werklikheid van die mens bymekaar kom. Die mens kom op ' $n$ werklikheid af wat geen duim terugstaan nie, maar wat die mens dwing om stelling in te neem. Die mens kry nie die kans om op eie werke en moontlikhede terug te val nie. Die mens word tot in sy fondamente geskud en in hierdie beproewing tot die ware mens gemaak, wat hy is. Die Goddelike wil maak aanspraak op die mens se wil. Van sy kant af kom God inagnemend na die mens toe. God hou rekening met die mens se sonde en skuld, die mens se soeke en oortuigings, klagtes en laster, bid en dank. God loop die mens nie onder stof nie, maar kom hom tegemoet. 
God se woord van versoening is vir die mens die antwoord die nood wat ervaar word. Dit is nie die antwoord soos die mens dit uitgedink het nie, maar God se eie antwoord. En God vra van die mens gehoorsaamheid as hy wil lewe. Die mens se verlorenheid word nou die belydenis van sy skuld en hy ontvang van God genade. Die mens word deur God geoordeel en nuutgemaak. Die mens word deur die genade, wat soos 'n oordeel werk, by homself uitgebring. Deur Nagmaal te gebruik, verkondig die gemeente 'die dood van die Here totdat Hy kom' (1 Kor 11:26), dit wil sê, dat oordeel en genade saamval. Die mens verstaan homself as begenadigde sondaar en hierdie nuwe verstaan van homself het die mens nooit op sy eie nie, maar net in die ontmoeting, voor God. Die nuwe begrip wat hy van homself het, word nie soseer met die verstand verkry nie, maar met die hart. Die erediens gee vorm en uitdrukking aan die besef van die betekenis van hierdie ontmoeting. Die mens hoor wat God sê en God hoor wat die mens sê, daar kom nie 'n dooie punt nie.

In die lig van bogenoemde moet 'n vraagteken geplaas word agter die liturgiese gepastheid van kommentaar in die erediens soos: 'God het ons met sy seën gegroet. Laat ons met blydskap daarop antwoord deur te sing van ...' (Nederduitsch Hervormde Kerk van Afrika 1987:50). Die formule beskryf 'n direkte teenwoordigheid en 'n wisselwerking wat nie werklik by die aard van die geloof pas nie. Die ontmoeting kry hiermee die karakter van 'n afspraak, 'n georganiseerde byeenkoms en die kerk word 'n heilsinstituut. Die erns van die uitdrukking ontmoetingsgebeure wil egter juis uitspel dat dit vir die mens ' $n$ te beurt val van genade is en dat hy hom nie moet vergryp nie.

Wanneer die kerk as erediens as ontmoetingsgebeure beskryf word, kan dit nie 'n vanse!fsprekende kontinuïteit besit nie. In sy wese is elke erediens nuut. Die kerk is die sigbare, of liewer hoorbare, wêreldlike gebied van bepaalde gebeure, naamlik dat die ou wêreld tot 'n einde kom en die nuwe aanbreek. Die verandering van die bedelings kan nie gesien word nie, wat sigbaar is, dit wil sê, wat hoorbaar is, is dat die Woord verkondig word en mense daarna luister. Die kerk is creatura verbi. Rondom die aktuele verkondiging ontstaan die sanctorum communio. Die evangelie vernietig die ou mens en haal hom uit sy vereensaming, ook uit sy godsdienstige afsondering, en stel hom in die gemeente. Die konkrete gemeente is tegelyk deel van die een dogmatiese gemeenskap, kerk, waarin alle wêreldlike verskille opgehef is, want dit is die wêreld wat met God versoen word. 'Dit maak nie saak of iemand Jood of Griek, slaaf of vry, man of vrou is nie: in Christus Jesus is julle almal een' (Gal 3:28). Die heil word verkondig en in geloof aangeneem en nie sosiologies georganiseer nie, en daarom geld dit ook dat 'in die samelewing elkeen (moet) bly in die omstandighede waarin hy was toe God hom geroep het' (1 Kor 7:20). Die opname in die erediensgemeente beteken die versoening met God. En die spreuk 'buite die kerk geen saligheid', is in die sin van kerk as eskatologiese heilsgemeenskap waar. Die kerk is die manier waarop die gemeenskap van die heiliges eskatologies kan bestaan. 


\section{DIENSAMP}

Op grond van die voorafgaande kan gesê word dat die kerklike erediens God se ordening is, dit wil sê, dit geskied op die gesag van God. Dit is die manier waarop die eskatologiese heil aan die wêreld gebring word. In die erediens is die heil aktueel teenwoordig en neem God sy gemeente in diens en plaas hulle op die pad om die versoeningswoord aan mense te verkondig. Die opvatting oor die kerklike amp kan nie hiervan losgemaak word nie. Die Woord moet verkondig word en die sakramente bedien word, daarom het die kerk bedienaars van die Woord en van die sakramente nodig (Rom 10:14). Die kerklike ampte word deur die Woord begrond. Vir sowel die apostel, wat aanvanklik deur die vrye werking van die Gees geroep is, as vir die ampsdraer wat later met oplegging van hande georden is, geld dat hulle aan die Woord onderwerp is. Die tradisionele teenstelling behoort nie tussen die charismatiese en verkose ampsdraers ingevoer te word nie, want die gemeente kies diegene wat volgens die maatstaf van die Gees gekeur is (vgl 1 Tim $1: 18 ; 4: 14)$ en die handoplegging wil as gebedshandeling te kenne gee dat God self optree. Beide, amp en charisma, word deur diens gekenmerk. Wat gedoen moet word, is dat die woord van versoening verkondig moet word, sodat Christus se heilswerk kan wees wat dit is: die aanbreek van die nuwe bedeling.

Die geskiedenis van die kerk toon dat die dienskarakter van die begin af bedreig is en maklik verdring kan word deur die sug om te heers. Jakobus en Johannes wou al aan die regterhand en aan die linkerhand van die heersende Koning Jesus sit (Mark 10:37; Schmithals 1979:463-465). Indien ons van die tradisionele onderskeid gebruik wil maak, is die gevaar nie groter by die geordende dienaar, dat die Gees in 'n ampsgees ontaard, as by die charismatiese dienaar, dat sy/haar diens in willekeurigheid eindig nie. Vir altwee geld dat die charisma en amp net as die bediening van die versoening geformuleer kan word. Die waarborg lê nie by die amp of die ampsbekleër nie, maar daarin dat hy/sy in diens staan van die Woord.

In die bediening van die versoening doen die gemeente self die werk. Dit is werk wat deur die gemeente gedoen word en nie deur iemand aan die gemeente, waar die gemeente die voorwerp van die handeling sou wees nie. Omdat hulle aan die wêreld verkondig dat God goed is, ervaar hulle self ook God se goedheid. Op grond van die goddelike opdrag aan die gemeente om die evangelie te verkondig, doen die gemeente 'n werkverdeling en wys mense aan om bepaalde take te verrig. So 'n werkverdeling berus op die opdrag wat van God af kom en moet nie misverstaan word en teruggevoer word na ' $n$ ooreenkoms wat tussen eendersvoelende mense bereik is nie. Die gemeente kan nie onderling ooreenkom dat hulle ook verder hulle predikant sal aanvaar omdat hulle tevrede met hom/haar is en byvoorbeeld meen dat hy/sy 'n groot seun/dogter van sy/haar volk is nie. So 'n volksbesluit is nie 'n erkenning van die amp van die diena(a)r(es) van die Woord nie, maar die afskaffing daarvan. 
Die gedagte dat die gemeente van 'n afsonderlike organisasie gebruik kan maak om sy dienswerk in die wêreld te verrig, kom nie in die gesigsveld van die opdrag aan die kerk nie. Daar tree nie 'n ander orgaan na vore wat die kerk kan bystaan nie. Die kerk kan sy morele geloofwaardigheid egter goed gebruik om bepaalde lofwaardige doelwitte in ' $n$ samelewing te bereik, en so kan die kerk self ook aktief aan die gemeenskapsbedrywighede deelneem. Waar die kerk die boodskap van versoening prysgegee het, is sulke aktiwiteite ook die enigste selfverdediging wat vir die kerk oorbly. En ongemerk word die kerk 'n orgaan wat bystand aan die gemeenskap verleen. Die Nederduitsch Hervormde Kerk behoort so byvoorbeeld sy verbintenis met Die Ondersteuningsraad in heroorweging te neem.

Waar die eskatologiese heil verkondig word, kom die verganklike wêreld in die ware lig te staan. Dit word duidelik dat die mens nie die heil van die wêreld, van die mens self, van die beplanning en programme van mense moet verwag nie. Die gelowige onderskei tussen die ryk van God en die ryke van die wêreld. Die Christen leef sy geloof in die regiment waar God met sy regterhand regeer, die eskatologiese ryk, die nuwe skepping. Dit is die regiment waar God se genade en sy geregtigheid heers en die mens kry toegang tot hierdie ryk deur skuldbelydenis en geloof, en ontvang hier vergewing van sonde. Hierdie ryk is opgerig 'op grond van die groot ontferming van God' (Rom 12:1).

Tegelyk leef die Christen ook in die regiment waar God met sy linkerhand regeer; die ryke van die wêreld, die skepping. Hier gaan dit om die verganklike welsyn van mense. Hier strewe die gelowige, saam met alle ander mense, na beter toestande, na 'n hoër mate van reg en geregtigheid, na 'dit wat waar is, wat edel is, wat reg is, wat aangenaam is, wat prysenswaardig is, watter deug of lofwaardige saak daar ook is' (Fil 4:8). Die liefdediens wat die gelowige in hierdie ryk verrig, is nie te onderskei van die optrede van 'n sedelik verantwoordelike persoon nie. Wat hier gevra word, is om so verstandig as moontlik met die beskikbare middele te werk. Die onderskeid wat dikwels in ons geledere gemaak word tussen barmhartigheidsdiens, dit wil sê, die liefdediens wat deur gelowiges verrig word, en gewone menslike hulp, kan in werklikheid nie gemaak word nie. Deur die werke van gelowiges met 'n waas van geheimsinnigheid te omhul en dit in onderskeid van wat ander mense doen, as 'Christelik' voor te hou, word 'n verkeerde indruk geskep. Enersyds weet gelowiges naderhand nie meer wat om te doen, sodat dit Christelik kan wees nie en andersyds kan ander mense begin dink dat as iemand net menslik wil wees, so 'n persoon nie 'n Christen moet word nie. Die gelowige doen egter ook wat die ander doen en weet ook, dat waar misluk word, waar insig te kort skiet, die gelowige nog deur God vasgehou word. 


\section{KERK EN CHRISTEN}

Die kerk het die opdrag om die evangelie te verkondig. Die praktyk van die kerk is om te preek. Deur die arbeid van die kerk word die heil gebring en mense met God versoen. Aan hierdie opdrag van die kerk is ook die kerklike amp en ampsdraer as sodanig gebind. Die kerk verstaan homself nie as 'n politieke grootheid nie, maar as die ryk van God in duidelike onderskeid met die ryke van die wêreld. Politieke profesie, waar die ampsdraer of ampdraers hulle ampshalwe oor aktuele politieke vraagstukke uitlaat, wil die kerk terugpluk uit die nuwe bedeling en in die oue inbring en is in die verlede nog altyd deur die kerk as sektaries afgewys. 'n Mooi formulering van hierdie neiging is by Rautenbach (1978:78-79) te lees wanneer hy politieke profesie aanbeveel as 'profetiese deurligting van die politieke orde deur prediking, belydenis, getuienis, herderlike briewe, kanselboodskappe ens'. Dit kan op niks anders uitloop as om politieke gedrag direk in die evangelie te begrond nie. Die profetiese amp in die kerk kan geen ander inhoud hê as die eskatologiese boodskap nie.

Die kerk behoort nie te probeer om met profetiese gesag die een of ander politieke mening voor te dra nie (Schmithals 1986:33). Aan die een kant is dit die kerk se opdrag om die boodskap van vergewing van sonde te verkondig. Dit is wat die wêreld nodig het om van die kerk te hoor. Niemand anders bring hierdie tyding nie. Aan die ander kant word politieke vraagstukke opgelos deur voorstelle wat vir Christene sowel as nie-Christene oortuigend is. Sulke voorstelle kan nie die status van onfeilbare waarheid hê nie. Die gepaste omgang met sulke voorstelle is om hulle in die praktyk van elke dag te oorweeg met die besef dat die vrae en kwellinge daarmee nie ophou nie.

Deur die kerklike verkondiging word gelowiges in die wêreld vrygestel om hulle verantwoordelikhede te aanvaar. In hulle diens word die mens, die humaniteit, die lewe vooropgestel en nie wêreldbeskouings of drukgroepe nie. Die menslikheid word gedien, nie omdat die mens die hoogste waarde is en die politiek daarom heilig is nie, maar omdat die Christen sy geloof in liefde bewaar word. Die gelowige kan nie anders as om polities betrokke te wees nie. Die gelowige het die moed om aan die politiek deel te neem omdat die gelowige se planne nie goddelik-volmaak hoef te wees nie. Die gelowige se bedoeling is nie soos God dit sou bedoel nie. Ook as die gelowige se planne misluk, bly die wêreld nog in God se hand. Daarom kan die gelowige na eie goeddunke handel. Die gelowige weet ook dat die ryke waarin liefdediens verrig word, nie die ryk van God is nie en ook nie voorlopers van die ryk van God nie, en die wete bewaar die gelowige van oormoedigheid. So word huise gebou waarvan die mure kraak. Die werk van gelowiges is nie heilswerk nie. 
Die Christene kry van die skrywer van Kolossense die volgende raad:

Tree met wysheid op teenoor die mense wat nog buite die gemeente is. Maak die beste gebruik van elke geleentheid. Wat julle sê moet altyd vriendelik wees en van goeie smaak getuig; en julle moet weet hoe julle elkeen behoort te antwoord.

(Kol 4:5-6)

Die apostel bedoel nie dat die gemeentelede moet rondloop en deurlopend aan mense moet verduidelik dat hulle gelowiges is nie. Mense wat hierdie indruk skep, verdraai die bedoeling en plaas gelowiges onder 'n dwang om met hulle geloof te presteer. Druk word op veral jong, onervare gelowiges uitgeoefen deurdat die indruk geskep word dat dit nie genoeg is om te glo nie, daar moet ook nog iets ekstra met die geloof gedoen en bereik word. Maar uitbranding is die voorland van 'n lewe wat só vêr bo sy werklike vermoë gevoer moet word. Paulus se bedoeling was egter nie om die gemeente so te laat rondgaan en hulle afhanklik te stel van die indruk wat hulle op ander maak nie. Hy was minder swaarmoedig en meer beskeie en daarom ook redeliker en mensliker, nader aan die waarheid as hy sê 'tree met wysheid op', wysheid wat onderskei tussen dit wat 'n mens kan doen en dit wat God kan doen. 'n Mens kan leef as 'n gelowige en God kan toesien dat die gelowige se lewe vir iemand anders betekenis kan hê. 'Koop die tyd uit': benut elke geleentheid om as Christen te lewe, wees vriendelik in 'n wêreld waar harde woorde die deurslag gee, wees geduldig, selfbeheersd. Troos die wat vertwyfeld is. Dit kan gebeur dat iemand nader staan en wil weet hoe die gelowige dit regkry. Op hierdie vraag gee die gelowige dan 'n duidelike antwoord, vriendelik en op die man af.

\section{SLOTOPMERKINGS}

Miskien kan die beskuldiging gemaak word dat ek te veel vrae opgeroep het en te min praktiese oplossings aangebied het, dat ons kerklike bestaan nie makliker word nie, maar moeiliker. So 'n klagte sal my egter nog nie van stryk bring nie, want indien dit wat gesê is, daarin sou slaag om ons onrustiger te maak, onrustig oor onsself, deurdat ' $n$ beroep op ons teologiese verantwoordelikheid gedoen word, sou hierdie paar bladsye die moeite werd wees. En daarmee het ek nog niks nuuts gesê nie, want ons almal weet dat ons verantwoordelikheid inhou dat ons ons laat terugdwing na die enigste grondslag wat vir die kerk en die Christelike teologie gelê is, naamlik Jesus Christus.

\section{Literatuurverwysings}

Bultmann, R [1926] 1963. Die Frage der 'dialektischen' Theologie: Eine Auseinandersetzung mit Erik Peterson, in Moltmann, $\mathrm{J}$ (Hrsg), Anfänge der dialektischen Theologie, Teil II, 72-92. München: Kaiser. (Theologische Bücherei, Band 17.) 
Bultmann, R [1952] 1971. Brief an Prof. K Barth, in Jaspert, B, Karl Barth - Rudolf Bultmann: Briefwechsel 1922-1966, 169-195. Zürich: Theologischer Verlag. (Karl Barth Gesamtausgabe, V. Briefe, Bd. 1.)

Du Plessis, K [1981] 1988. Kinders van die wind en ander lirieke met wysies en akkoorde. Ingelei deur Hennie Aucamp. Kaapstad: Tafelberg.

Gunneweg, A H J 1967. Zerrbilder von Gott, in Kutschki, N (Hrsg), Gott heute: 15 Beiträge zur Gottesfrage, 85-92. Mainz: Grünewald.

- 1977. Vom Verstehen des Alten Testaments: Eine Hermeneutik. Göttigen: Vandenhoeck. (ATD Erganzungsreihe, Band 5.)

- 1993. Biblische Theologie des Alten Testaments: Eine Religionsgeschichte Israels in Biblisch-theologischer Sicht. Stuttgart: Kohlhammer.

Lietzmann, H 1969. An die Korinther I, II. Tübingen: Mohr.

Loader, J A 1979. Waarom sing ons in die kerk?, in Loader, J A (red), ' $n$ Nuwe lied vir die Here, 160-177. Pretoria: HAUM.

Nederduitsch Hervormde Kerk van Afrika 1987. Diensboek. Pretoria: Kital.

Rautenbach, C H 1978. Die toekoms van die kerk in die samelewing: Kollig op die sosiaal-etiese, insluitende politieke afmetings van Christelike kerk-bly in SuidAfrika, in Vorster, W S (red), Church and society, 68-97. Pretoria: UNISA.

Schmithals, W 1979. Das Evangelium nach Markus, 2 Bde. Gütersloh: Mohn. (TK 2/1; 2/2; GTB-Siebenstern 502; 503.)

- 1986. Politisches Handeln verträgt kein Amen. Der Tagesspiegel 19.11.1986, 33.

- 1988. Der Römerbrief: Ein Kommentar. Gütersloh: Mohn.

- 1994. Theologiegeschichte des Urchristentums: Eine problemgeschichtliche Darstellung. Stuttgart: Kohlhammer.

Van Selms, A 1949. A A van Ruler, droom en gestalte: Een discussie over de theologische principes in het vraagstuk van Christendom en politiek. HTS 6, 6972.

Venter, F A 1966. Gelofteland. Tweede druk. Kaapstad: Tafelberg. 